\title{
Secular Trends in Anthropometrics and Physical Fitness of Young Portuguese School-Aged Children
}

\author{
Tendências Seculares dos Níveis Antropométricos e de \\ Aptidão Física em Crianças Portuguesas
}

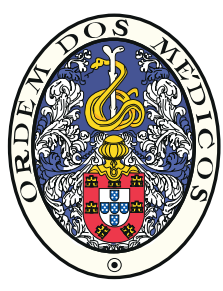

\author{
Aldo Matos COSTA $1,2,3$, Mário Jorge COSTA ${ }^{2,4}$, António Antunes REIS ${ }^{1}$, Sandra FERREIRA ${ }^{5}$, Júlio MARTINS ${ }^{1,2}$, \\ Ana PEREIRA $\bowtie 2,6,7$ \\ Acta Med Port 2017 Feb;30(2):108-114 - http://dx.doi.org/10.20344/amp.7712
}

\section{ABSTRACT}

Introduction: The purpose of this study was to analyze secular trends in anthropometrics and physical fitness of Portuguese children. Material and Methods: A group of 1819 students ( 881 boys and 938 girls) between 10 and 11 years old was assessed in their $5^{\text {th }}$ and $6^{\text {th }}$ scholar grade throughout a 20 years' time-frame. ANCOVA models were used to analyze variations in anthropometrics (height, weight and body mass index) and physical fitness (sit and reach, curl-up, horizontal jump and sprint time) across four quinquennials (1993 1998; 1998 - 2003; 2003 - 2008; 2008 - 2013).

Results: Secular trends showed the presence of heavier boys and girls with higher body mass index in the $5^{\text {th }}$ and $6^{\text {th }}$ grade throughout the last 20 years. There was also a presence of taller girls but just until the $3^{\text {rd }}$ quinquennial. Both boys and girls were able to perform better on the core strength test and sprint time but become less flexible over the years. Mean jumping performance remained unchanged for both genders.

Discussion: The present study provides novel data on anthropometrics and physical fitness trends over the last two decades in young Portuguese children, consistent with the results reported in other developed countries.

Conclusion: Evidence for the start of a positive secular trend in body mass index and in some physical fitness components over the last two decades among the Portuguese youth.

Keywords: Anthropometry; Body Mass Index; Child; Growth and Development; Physical Fitness; Portugal

\section{RESUMO}

Introdução: Analisar as tendências seculares ao nível da antropometria e aptidão física das crianças portuguesas.

Material e Métodos: Um grupo de 1819 crianças (881 rapazes e 938 raparigas) entre os 10 e os 11 anos de idade, foi avaliado no $5^{\circ} \mathrm{e}$ $6^{\circ}$ ano de escolaridade durante 20 anos. A ANCOVA foi usada para analisar as variações de antropometria (índice de massa corporal, peso e altura) e aptidão física (sentar e alcançar, força abdominal, salto horizontal e corrida de velocidade) durante quatro quinquénios (1993 - 1998; 1998 - 2003; 2003 - 2008 e 2008 - 2013).

Resultados: As tendências seculares mostraram a presença de crianças mais pesadas e com um índice de massa corporal mais elevado ao longo dos últimos 20 anos. Verificou-se também a presença de raparigas mais altas, mas só até ao terceiro quinquénio. Ambos os géneros melhoraram o desempenho nos testes de força abdominal e corrida de velocidade mas pioram a sua capacidade de flexibilidade ao longo dos anos. O desempenho no salto horizontal permaneceu inalterado em ambos os géneros.

Discussão: Este estudo fornece novos dados sobre a tendência dos registos antropométricos e de aptidão física nos últimos 20 anos em crianças Portuguesas, sendo consistente com as tendências reportadas sobre outros países desenvolvidos.

Conclusão: Os resultados sugerem uma tendência positiva nos últimos 20 anos no índice de massa corporal e em alguns componentes da aptidão física em crianças Portuguesas.

Palavras-chave: Antropometria; Aptidão Física; Crescimento e Desenvolvimento; Criança; Índice de Massa Corporal; Portugal

\section{INTRODUCTION}

In recent years, there has been an increasing interest in describing the physical fitness levels of young people, particularly in relation to health benefits and wellness. According to several authors, physical fitness is not only an important value in contemporary society, but also has fundamental significance in the intent to be active. ${ }^{1-3}$

Overall, physical fitness can be considered as the adjustment of individuals to the physical and social environment. ${ }^{3,4}$ In the health context, physical fitness is generally defined as a state characterized by the ability to carry out daily vigour tasks demonstrating traits and capacities associated with low risk of premature development of hypokinetic diseases. ${ }^{5}$ One of the most disturbing aspects of the $21^{\text {th }}$ century is the obesity prevalence through childhood. This phenomenon has classified obesity as a public health problem, among diabetes, hypertension, sleep apnea and psychological disturbances including depression and low self-esteem. ${ }^{6-8}$

The relation between obesity with physical fitness in children is a quite complex problem. Several reports

1. Department of Sport Sciences. Universidade da Beira Interior. Covilhã. Portugal.

2. Research Centre in Sports Sciences, Health Sciences and Human Development (CIDESD). Universidade de Trás-os-Montes e Alto Douro. Vila Real. Portugal.

3. Health Sciences Research Centre. Universidade da Beira Interior. Covilhã. Portugal.

4. Department of Sport Sciences. Instituto Politécnico da Guarda. Portugal.

5. Department of Mathematics and Center for Mathematics. Universidade da Beira Interior. Covilhã. Portugal.

6. Department Science and Technology. Instituto Politécnico de Setúbal. Setúbal. Portugal.

7. Research Centre in Education - CIEF. Instituto Politécnico de Setúbal. Setúbal. Portugal.

$\triangle$ Autor correspondente: Ana Pereira. anapereiraphd@gmail.com

Recebido: 06 de abril de 2016 - Aceite: 14 de novembro de 2016 | Copyright @ Ordem dos Médicos 2017 
demonstrate that a decrease in physical activity promote unhealthy eating behaviors, increasing the susceptibility to obesity. ${ }^{9}$ Besides, the high prevalence of unfavorable lifestyles and the aggregation of risk factors, emphasize the adverse cardiovascular risk profile at younger ages. ${ }^{10}$ Nowadays, there are enough evidences to admit that active lifestyles in combination with other positive elements, such as fruit and vegetable intake, control of abdominal obesity, arterial tension and lipidemia, can be beneficial to health and reduce overweight. $5,11,12$

The most recent studies also found a very negligible effect in body composition ${ }^{13}$ and physical fitness status ${ }^{14}$ of students participating exclusive in physical education classes. The regular practice of exercise programs outside of school, in clubs or gyms, also proved to be important components in the obesity treatment. ${ }^{15}$ However, little is known about anthropometrics and physical fitness trends over long time-periods, with direct social, demographic and economic impact. Over the last 20 years the society patterns of education, transportation and leisure changed dramatically, leading to a decrease in the time available for physical exercise. ${ }^{16}$ Recent meta-analyses reported global changes in several health-related physical fitness components ${ }^{17,18}$ namely a decrease in cardiorespiratory fitness and stabilisation in muscular strength. However, the literature is quite inconsistent, and the most of the available data on the topic comes from countries at the earliest stage of social and economic development. Particularly with regard to the pediatric aerobic fitness, there seems to a sharp decline since 1970 among children (6 to 19-years-old) from 27 countries. ${ }^{17}$ The pattern of change of all the other components of physical fitness in school-aged children seem to be more inconsistent; some studies have reported a physical fitness decline, while other studies have reported no changes between decades or even increases. ${ }^{18-21}$

This secular changes in pediatric physical fitness may result from multiple factors; the socio-cultural context is one of the most determinant factor that probably triggers a positive relationship between a healthy lifestyle and physical fitness. ${ }^{22}$ Understanding local or national trends in physical fitness and obesity are important inputs to identifying successful and less successful strategies. ${ }^{19}$ This type of knowledge would allow us to redefine organizations, and act more effective in promoting healthy behaviors through physical participation.

This study comprises a time of relevant social-economic and demographic changes in Portugal, resulting in challenging health consequences of sedentary behaviour in children and adolescents. ${ }^{23}$ The aim of this study was two-fold: (i) describe secular trends in physical fitness and obesity in 10 and 11-years-old Portuguese from an urban high school located in the northern interior of Portugal; (ii) analyze quinquennial effects in different physical tests considering age and body mass index (BMI) as covariates Articulated on the basis of existing knowledge, it was hypothesized that secular changes in physical fitness of 10 and 11-years-old Portuguese children would improve obesity associated with sociodemographic processes.

\section{MATERIAL AND METHODS \\ Study participants}

This is a descriptive, non-randomized study, conducted to determine trends over time (over the last 20 years) in BMI and physical fitness of Portuguese school-aged children. The study participants were recruited in the region of Beira Interior (in North-Eastern Portugal) by a non-probabilistic sampling method. ${ }^{24}$ The subjects were selected because of their convenient accessibility and proximity to the researcher over the last two decades. Inclusion criteria during this study were as follows: 10 and 11-years-old students of both genders attending the physical education classes $\left(5^{\text {th }}\right.$ and $6^{\text {th }}$ grade) in the last 20 years (from the scholar year 1993/1994 to $2012 / 2013$ ) but on only one occasion. Students who have been retained at least one year throughout their course were excluded.

A total of 1819 students (881 boys and 938 girls) were included for further analysis over four consecutive quinquennials (1993 - 1998; 1998 - 2003; 2003 - 2008; 2008 - 2013) (Table 1). The confidentiality of data was guaranteed, as well as anonymity in the treatment process and analysis. All ethical standards provided according to the Helsinki Declaration in respect to human research were considered. The procedures were annually laid down in the regulation of the school. All evaluations were performed by trained technicians. Participants and their parents were fully informed about the protocol before participating.

Table 1 - Sample size of each age gender from the 1993 to 2013

\begin{tabular}{|c|c|c|c|c|c|c|}
\hline Gender & $\begin{array}{l}\text { School } \\
\text { year }\end{array}$ & $\begin{array}{c}1^{\text {st }} \text { quinquennial } \\
(1993-1998)\end{array}$ & $\begin{array}{c}2^{\text {nd }} \text { quinquennial } \\
(1998-2003)\end{array}$ & $\begin{array}{c}3^{\text {rd }} \text { quinquennial } \\
(2003-2008)\end{array}$ & $\begin{array}{c}4^{\text {th }} \text { quinquennial } \\
(2008-2013)\end{array}$ & $\begin{array}{c}\text { Total } \\
(1993-2013)\end{array}$ \\
\hline \multirow{2}{*}{ Boys } & $5^{\text {th }}$ grade & $\begin{array}{c}10.30 \pm 0.28 \\
(n=165)\end{array}$ & $\begin{array}{c}10.22 \pm 0.28 \\
(n=74)\end{array}$ & $\begin{array}{c}10.30 \pm 0.27 \\
(n=93)\end{array}$ & $\begin{array}{c}10.29 \pm 0.29 \\
(n=127)\end{array}$ & $\begin{array}{c}10.28 \pm 0.28 \\
(n=459)\end{array}$ \\
\hline & $6^{\text {th }}$ grade & $\begin{array}{c}11.31 \pm 0.28 \\
(n=64)\end{array}$ & $\begin{array}{c}11.29 \pm 0.38 \\
(n=124)\end{array}$ & $\begin{array}{c}11.26 \pm 0.29 \\
(n=58)\end{array}$ & $\begin{array}{c}11.25 \pm 0.28 \\
(n=135)\end{array}$ & $\begin{array}{c}11.27 \pm 0.32 \\
(n=381)\end{array}$ \\
\hline \multirow{2}{*}{ Girls } & $5^{\text {th }}$ grade & $\begin{array}{c}10.22 \pm 0.28 \\
(n=155)\end{array}$ & $\begin{array}{c}10.29 \pm 0.27 \\
(n=89)\end{array}$ & $\begin{array}{c}10.28 \pm 0.27 \\
(n=119)\end{array}$ & $\begin{array}{c}10.29 \pm 0.29 \\
(n=110)\end{array}$ & $\begin{array}{c}10.26 \pm 10.28 \\
(n=473)\end{array}$ \\
\hline & $6^{\text {th }}$ grade & $\begin{array}{c}11.29 \pm 0.31 \\
(n=82)\end{array}$ & $\begin{array}{c}11.26 \pm 0.28(n= \\
133)\end{array}$ & $\begin{array}{c}11.26 \pm 0.28 \\
(n=63)\end{array}$ & $\begin{array}{c}11.26 \pm 0.28 \\
(n=149)\end{array}$ & $\begin{array}{c}11.27 \pm 0.29 \\
(n=427)\end{array}$ \\
\hline
\end{tabular}


The study had a duration of 20 years with regular standard measurements at the beginning of each scholar year. Physical fitness and anthropometric scores were always assessed by the same researcher ensuring the reliability of the data collected. Every year the researcher spent a previously training period to refine the data collection technique using a small sample of subjects not covered in this study (around 15 subjects). The evaluation program included anthropometric and various health-related physical fitness tests designed to assess muscle strength, muscular endurance, speed and flexibility.

The evaluation process selected protocols that were efficient and that had been previously used in several studies for the assessment of anthropometry in young people..$^{25}$ All testing procedures were applied to all participants. The subjects followed a familiarization session before testing to reduce the effects of any differences in learning. The standardized tests were completed in two sessions separated by 48 hours. On day one, the participants were assessed anthropometric measures, and in the second session, the participants were assessed for physical fitness assessment. All participants were motivated to give their maximum effort during performance measurements.

\section{Instruments}

Anthropometric assessment: Total height $(\mathrm{m})$ was measured to the nearest 1.0 centimeter with a portable stadiometer (Holtain Ltd, UK) and body weight $(\mathrm{kg})$ were measured was measured to the nearest 0.1 kilogram with a calibrated scale over time (Seca, Germany) according to international standards for anthropometric assessment ${ }^{26}$ in a private setting while students were dressed in light clothing in the morning. Body mass index (BMI) was mathematically estimated according with the equation $\mathrm{BMI}=$ weight $/$ height $^{2}$ $\left(\mathrm{kg} / \mathrm{m}^{2}\right)$.

\section{Physical fitness assessment}

The participant's physical fitness was evaluated always in the morning and during three consecutive physical education (PE) classes. For muscle fitness evaluation, we used horizontal jump test (without preparatory running) and it was performed always in the first PE class. The abdominal muscle endurance (curl-up) and running velocity (in $40 \mathrm{~m}$ ) were evaluated in the second PE class. Finally the hamstring flexibility was evaluated in the third PE class by the sit-andreach test. All tests were completed according to physical fitness test batteries that are commonly administered to school children in several countries: the AAHPERD ${ }^{27}$ (the standing long jump test and the $40 \mathrm{~m}$ sprint) and the Fitnessgram test batteries (the curl-up test and the seat and reach flexibility test). ${ }^{28}$

The participants were familiarized with each test through demonstration and were allowed to practice the testing protocols before the real trials. They were randomly assigned to perform the first test and the starting order was always the same for the following tests to ensure the absence of a fatigue effect. At the beginning participants performed a general warm-up walking in the gym and promoting the articulation of all body joint articulation.

\section{Statistical analysis}

Data was analyzed using SPSS software (version 21.0). The normality and homoscedasticity assumptions were checked respectively with the Kolmogorov-Smirnov and the Levene Tests. Participants were organized by birth year intervals ( $5^{\text {th }}$ and $6^{\text {th }}$ grade students). Descriptive statistics (mean $\pm \mathrm{sd}$ ) were calculated for all time periods. Repeatedmeasures ANOVA was used to assess the variations in anthropometric and physical fitness scores over time. ${ }^{29}$ The Tukey test was used for post-hoc analysis when the F-ratio was significant. ANCOVA was used with age as covariate and quinquennials as factor for anthropometric scores.

Table 2 - Age adjusted means + standard error for height, weight and BMI in boys and girls by time period (ANCOVA results)

\begin{tabular}{|c|c|c|c|c|c|c|c|c|c|c|c|c|c|}
\hline & & \multicolumn{2}{|c|}{$1^{\text {st }}$ quinquennial } & \multicolumn{2}{|c|}{$2^{\text {nd }}$ quinquennial } & \multicolumn{2}{|c|}{$3^{\text {rd }}$ quinquennial } & \multicolumn{2}{|c|}{$4^{\text {th }}$ quinquennial } & \multirow{2}{*}{$\mathbf{F}$} & \multirow{2}{*}{$p$} & \multirow{2}{*}{ 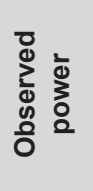 } & \multirow{2}{*}{ 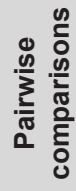 } \\
\hline & & M & $\pm \mathrm{SE}$ & M & $\pm \mathrm{SE}$ & M & $\pm \mathrm{SE}$ & M & $\pm \mathrm{SE}$ & & & & \\
\hline \multirow{3}{*}{ Boys } & $\begin{array}{l}\text { Height } \\
\text { (m) }\end{array}$ & 1.434 & 0.007 & 1.442 & 0.008 & 1.448 & 0.009 & 1.439 & 0.007 & 0.556 & 0.645 & 0.165 & - \\
\hline & $\begin{array}{l}\text { Weight } \\
\text { (kg) }\end{array}$ & 37.316 & 0.551 & 38.675 & 0.591 & 38.280 & 0.672 & 39.734 & 0.512 & 3.481 & 0.016 & 0.779 & $1<4$ \\
\hline & $\begin{array}{l}\text { BMI } \\
\left(\mathrm{kg} / \mathrm{m}^{2}\right)\end{array}$ & 18.051 & 0.200 & 18.204 & 0.215 & 18.140 & 0.243 & 18.770 & 0.186 & 2.836 & 0.037 & 0.682 & - \\
\hline \multirow{3}{*}{ Girls } & $\begin{array}{l}\text { Height } \\
\text { (m) }\end{array}$ & 1.443 & 0.004 & 1.464 & 0.005 & 1.462 & 0.005 & 1.452 & 0.004 & 4.497 & 0.004 & 0.882 & $\begin{array}{l}1<2 ; \\
1<3\end{array}$ \\
\hline & $\begin{array}{l}\text { Weight } \\
\text { (kg) }\end{array}$ & 37.437 & 0.549 & 40.754 & 0.566 & 39.469 & 0.624 & 40.080 & 0.523 & 6.584 & $<0.0001$ & 0.973 & $\begin{array}{l}1<2 \\
1<4\end{array}$ \\
\hline & $\begin{array}{l}\text { BMI } \\
\left(\mathrm{kg} / \mathrm{m}^{2}\right)\end{array}$ & 17.866 & 0.203 & 18.890 & 0.209 & 18.331 & 0.231 & 18.853 & 0.193 & 5.522 & 0.001 & 0.941 & $\begin{array}{l}1<2 ; \\
1<4\end{array}$ \\
\hline
\end{tabular}


A similar approach was performed with age and BMI as covariates and quinquennials as factor for physical fitness scores. The statistical significance was set at $p \leq 0.05$.

\section{RESULTS}

Table 2 presents the anthropometric scores for both genders when the effect of the covariate (age) was removed. Boys became heavier across time $(p=0.037)$ while their height remained unchanged within the four quinquennials ( $p=0.645$ ). On the other side, girls suffered significant changes in their height and weight $(p \leq 0.0001)$ and BMI $(p=0.001)$.

Table 3 presents the variation in physical fitness scores throughout the four quinquennials when the effect of the covariates (age and BMI) was removed. Children from the 1993 cohort were less flexible than those from 2013 ( $p<$ 0.01). Regarding speed, boys in 2013 were faster than their 1993 counterparts. Similar trend was found for girls but without statistical meaning. The curl-up assessment, showed a similar pattern in both genders, with better scores reached in the most recent quinquennial. Finally, horizontal jump performance also showed slight improvements throughout those years but without reaching the significance cut-of value.

\section{DISCUSSION}

The purpose of this study was to analyze the secular changes in anthropometrics and physical fitness in young Portuguese boys and girls between 1993 and 2013. In summary, our results our results showed increasing trends in BMI that corresponded in boys to a higher increase in weight than in height, while in girls to a similar increase in both parameters. We also reported improvements in physical fitness scores (except for horizontal jump), reflecting a positive influence of lifestyle and environmental changes throughout the last 20 years.

During this time period, novel education strategies were applied in Portugal, in order to encourage students' involvement in sport and physical activity. For example, from the year 1993, the 'school sport program' (organized by the coordinating office of schools sports at the Education Ministry) was officially included in the regular teaching schedule of Portuguese physical education teachers (and also within elementary schools for the first time). Sports program in schools began to represent a preferred vector for adding a set of experiences and opportunities for formal sports participation, as it could be difficult to get just with physical education session. Consequently, the number of students engaged in sport increased markedly. ${ }^{30}$ In addition, the Extracurricular Activities Program was formally

Table 3 - Age and BMI adjusted means \pm standarts errors for boys and girls physical fitness tests by time period

\begin{tabular}{|c|c|c|c|c|c|c|c|c|c|c|c|c|c|}
\hline & & $1^{\text {st }}$ quinq & ennial & $2^{\text {nd }} q u i n q$ & ennial & $3^{\text {rd }}$ quinq & ennial & $4^{\text {th }}$ quinq & ennial & & & & פ \\
\hline & & M & \pm SE & M & \pm SE & M & $\pm \mathrm{SE}$ & $M$ & \pm SE & & & & 0 o \\
\hline & $\begin{array}{l}\text { Sit and reach } \\
\text { (cm) }\end{array}$ & -0.031 & 0.434 & -1.974 & 0.470 & -2.510 & 0.528 & -4.054 & 0.404 & 15. 407 & 0.000 & 1.000 & $\begin{array}{l}1<2 \\
1<3 \\
1<4 \\
2<4\end{array}$ \\
\hline Boys & $\begin{array}{l}\text { Curl ups } \\
\text { (reps.) }\end{array}$ & 15.160 & 0.372 & 13.678 & 0.400 & 14.600 & 0.453 & 16.655 & 0.346 & 11.359 & 0.000 & 0.999 & $\begin{array}{l}1<2 \\
1<4 \\
2<4 \\
3<4\end{array}$ \\
\hline & $\begin{array}{l}\text { Horizontal } \\
\text { jump }(\mathrm{cm})\end{array}$ & 138.045 & 1.677 & 139.644 & 1.800 & 135.284 & 2.041 & 141.739 & 1.561 & 2.249 & 0.081 & 0.570 & - \\
\hline & $\begin{array}{l}\text { Sprint time } \\
\text { (sec.) }\end{array}$ & 7.906 & 0.043 & 7.854 & 0.046 & 7.700 & 0.052 & 7.717 & 0.039 & 5.279 & 0.001 & 0.930 & $\begin{array}{l}1>3 \\
1>4\end{array}$ \\
\hline & $\begin{array}{l}\text { Sit and reach } \\
(\mathrm{cm})\end{array}$ & 2.899 & 0.398 & 1.478 & 0.410 & 0.514 & 0.452 & -1.147 & 0.380 & 18.892 & 0.000 & 1.000 & $\begin{array}{l}1>3 \\
1>4 \\
2>4 \\
3>4\end{array}$ \\
\hline Girls & $\begin{array}{l}\text { Curl ups } \\
\text { (reps.) }\end{array}$ & 11.460 & 0.349 & 10.631 & 0.358 & 12.761 & 0.394 & 13.832 & 0.331 & 16.956 & 0.000 & 1.000 & $\begin{array}{l}1<4 \\
2<3 \\
2<4\end{array}$ \\
\hline & $\begin{array}{l}\text { Horizontal } \\
\text { jump (cm) }\end{array}$ & 124.510 & 1.669 & 128.463 & 1.715 & 122.105 & 1.886 & 127.546 & 1.585 & 2.583 & 0.052 & 0.637 & - \\
\hline & $\begin{array}{l}\text { Sprint time } \\
\text { (sec.) }\end{array}$ & 8.280 & 0.045 & 8.178 & 0.047 & 7.934 & 0.051 & 8.144 & 0.043 & 8.927 & 0.000 & 0.996 & $\begin{array}{l}1>3 \\
2>3 \\
3<4\end{array}$ \\
\hline
\end{tabular}


established by decision of the Minister of Education of Portugal in 2006, which included organized sports and physical activities for children in basic education. This program aimed to guarantee access to all students to larger spectre of activities that would add value to their school program with the objective of developing the child's capacity in several domains (e.g.: psychomotor, social-affective and cognitive).

Our results showed significant differences across time for boys in their weight and BMI, but not in height. This means that this secular trend for BMI in boys can be attributable to an increased body mass and not to body length. Among girls, significant changes in height and weight (and hence BMI) were found between 1993 and 2013. BMI variations in both genders over the last 20 years may be related to eating habits and physical activity, particularly during school activities or in leisure times. ${ }^{16}$ Those daily behaviours were not objectively measured in this study, limiting our interpretation. Nevertheless, as previously mentioned, there were more opportunities for children to be physical active outside the time normally devoted to the school curriculum in the last 20 years. However, it seems that the impact of novel sports strategies did not reach both genders in the same way. It seems that these programs were insufficient to counteract an increase in BMI, especially in boys, which grew at the expense of increased weight. A similar trend had been already reported by Cardoso and $P a d e z^{31}$ in a sample of high socio-economic status Portuguese boys during the last four decades. Authors stated that, this pattern of association between socio-economic status and obesity may reflect a late socio-economic transition of Portugal, and particularly in the inner centre region.

Our results showed a trend for an improvement in physical fitness over the last 20 years in both genders children of 2009 - 2013 had higher speed and core strength than their counterparts of 20 years before. This was an expected trend considering that there was an increase in lean body mass to support the weight gain observed in both genders, meaning extra strength. ${ }^{26}$ These findings concur with the secular trends reported in other young populations, whereas power and speed test performances improved at + $0.03 \%$ and $+0.04 \%$ per annum, respectively. ${ }^{17}$

Although using a different test to measure speed/agility (10 $\times 5$ m shuttle run), our data is consistent with the trend observed among Flemish boys and girls from 1979 - 1980 to $2005^{32}$ and, more recently, among Mozambicans girls (but not in boys) from 1992 to $2012 .{ }^{33}$ Though, our results differed from those found among Estonians and Lithuanians children (11 - 17 yrs) between 1992 to 2002, ${ }^{34}$ New Zealand children (10 -1 4 yrs) between 1991 and $2003^{35}$ and among Spanish adolescents between 2001 - 2002 and 2006 $2007^{36}$ where no statistically significant differences were found. Differences among these results could be related to sample characteristics and protocols (e.g., differences in running surfaces or practices runs). ${ }^{33}$ Issues related to motivation and opportunity for practice also act as confounders and cannot be controlled. ${ }^{37}$
A nonsignificant trend was observed for standing horizontal jump performance in both gender $(p=0.081$ and $p=0.052$, for boys and girls respectively). Given the fact that the secular improvement in performance is primarily a function of secular increase in body size ${ }^{37}$ children of 2009 2013 did not performed as well for their body size than their counterparts of 20 years before (1993 - 1997). Although our data was not plotted relative to mean height and weight, it reveals some stagnation in jumping performance already reported by other studies. Moliner-Urdiales et $a^{\beta 6}$ indicated a negative secular trend in standing broad jump performance from 2001 - 2002 to 2006 - 2007 among Spanish adolescents (12.5 - 17.5 years). Albon et a ${ }^{35}$ did not found significant differences in the standing broad jump performance among New Zealand children between 1991 and 2003. Besides, the changes in physical fitness could be also explained by changes in physical activity practice (quantity and type of activities).

Our results demonstrated a substantial reduction in children's flexibility over time. This negative trend in flexibility is similar to what was observed in Estonian and Lithuanian youth. ${ }^{34}$ Probably this can be explained by changes in body size (body height and weight); as previous reported, flexibility levels as assessed by the sit-and-reach test are dependent on body proportions. ${ }^{38}$ So, positive secular changes in growth patterns (namely leg length, trunk length, and arm length and their respective ratios), can explain, in part, that taller children of nowadays are less flexible than those from the past.

Notwithstanding the relevancy of the present results, some limitations should be addressed to the current study. First, no data about the children's play habits and/or objectively measured physical activity levels and patterns were available; engaging in extra sports activities may have imputed some bias in fitness levels. Further, behavioral habits such as the reduced time in sedentary activities, increases in engagement in active tasks during leisure time, and increasing effort to go in bicycle or walking to school, are considered effective to change fitness levels. ${ }^{23}$ Secondly, the use of field tests to measure health-related physical fitness components result in measurement errors at the individual level. In the present study, all measurements were assessed by the same researcher (ensuring the reliability of the data collected), according to the same methodology, which allows to minimize the systematic error to a value smaller. Thirdly no information about the participant's socialeconomic status were obtained; this would be valuable to understand the effects of various social and environmental factors that affect health behaviour with respect to the course of physical fitness over time. In the future, it will be appropriate to investigate lifestyle changes over time (affecting physical performance), comparing children with different levels of physical activity.

\section{CONCLUSION}

The present study indicates a tendency for increased weight among Portuguese children during the last 20 
years. Boys became heavier across time while their height remained unchanged within the four quinquennials. Girls seem to have changed significantly in their height, weight and BMI through time. The results also indicate a positive trend in speed and core strength, but a negative trend in flexibility. A nonsignificant trend was observed for standing horizontal jump performance in both sexes.

National policies on sport for health promotion implemented in the last 20 years encourage youth to be more physically active but did not develop all fitness components in the same way. Physical batteries performed each year of school may play an important role by helping to identify children with low physical fitness, and by promoting positive health behaviour's.

\section{PEOPLE AND ANIMALS PROTECTION}

The authors declare that the procedures were followed according to the regulations established by the Clinical Research and Ethics Committee and to the Helsinki Declaration of the World Medical Association.

\section{CONFIDENTIALITY OF DATA}

The authors declare having followed the protocols in use at their working center regarding patient's data publication.

\section{CONFLICTS OF INTEREST}

The authors declare that there are no conflicts of interest.

\section{FUNDING SOURCES}

No subsidies or grants contributed to this work.

\section{REFERENCES}

1. Louv R. Last child in the woods: saving our children from nature deficit disorder. Chapel Hill: Algonquin Books of Chapel Hill; 2005.

2. Corte de Araujo AC, Roschel H, Picanço AR, do Prado DM, Villares SM, de Sá Pinto AL, et al. Similar health benefits of endurance and highintensity interval training in obese children. PloS one. 2012;7:e42747.

3. Soares F, Ramos D. Overweight, obesity, physical activity, cardiorespiratory and muscular fitness in a Portuguese sample of high school adolescents. Minerva Pediatr. 2013;65:83-91.

4. Karpovitch. Physiology of muscular exercise. Philadelphia: Saunders; 1965.

5. Vasquez F, Diaz E, Lera L, Vasquez L, Anziani A, Burrows R. Impact of a strength training exercise program on body composition and cardiovascular risk factors in a group of obese school children by pubertal stage. Am J Sports Sci Med. 2014;2:40-7.

6. Dietz WH. Health consequences of obesity in youth: childhood predictors of adult disease. Pediatrics. 1998;101:518-25.

7. Nowicka P, Flodmark CE. Family in pediatric obesity management: a literature review. Int J Pediatr Obes. 2008;3:44-50.

8. Padez C, Mourao I, Moreira P, Rosado V. Prevalence and risk factors for overweight and obesity in Portuguese children. Acta Paediatr. 2005;94:1550-7.

9. Pieper JR, Laugero KD. Preschool children with lower executive function may be more vulnerable to emotional-based eating in the absence of hunger. Appetite. 2013;62:103-9.

10. Alves E, Henriques A, Correia S, Santos AC, Azevedo A, Barros H. Cardiovascular risk profile of mothers of a Portuguese birth cohort: a survey 4 years after delivery. Prev Med. 2013;57:494-9.

11. Blair RJ. A cognitive developmental approach to mortality: investigating the psychopathy. Cognition. 1995;57:1-29.

12. Siegrist M, Rank M, Wolfarth B, Langhof $H$, Haller B, Koenig W, et al. Leptin, adiponectin, and short-term and long-term weight loss after a lifestyle intervention in obese children. Nutrition. 2013;29:851-7.

13. Lowry R, Lee SM, Fulton JE, Demissie Z, Kann L. Obesity and other correlates of physical activity and sedentary behaviors among US high school students. J Obes. 2013;27:6318.

14. Ogden CL, Carroll MD, Kit BK, Flegal KM. Prevalence of obesity and trends in body mass index among US children and adolescents, 19992010. JAMA. 2012;307:483-90.

15. Fonseca-Junior SJ, Sa CG, Rodrigues PA, Oliveira AJ, Fernandes-Filho J. Physical exercise and morbid obesity: a systematic review. Arq Bras Cir Dig. 2013;26:67-73.

16. Adams KF, Leitzmann MF, Ballard-Barbash R, Albanes D, Harris TB, Hollenbeck A. Respond to "Body Mass Index and Mortality". Am J Epidemiol. 2013;179:147-8.

17. Tomkinson GR, Olds TS. Secular changes in pediatric aerobic fitness test performance: the global picture. Med Sport Sci. 2007;50:46-66.

18. Tomkinson GR. Global changes in anaerobic fitness test performance of children and adolescents (1958-2003). Scand J Med Sci Sports. 2007; 17:497-507.

19. Runhaar J, Collard DC, Singh AS, Kemper HC, van Mechelen W, Chinapaw M. Motor fitness in Dutch youth: differences over a 26-year period (1980-2006). J Sci Med Sport. 2010;13:323-8.

20. Thomas NE, Williams DR, Rowe DA, Davies B, Baker JS. Evidence of secular changes in physical activity and fitness, but not adiposity and diet, in Welsh 12-13 year olds. Health Educ J. 2010;69:381-9.

21. Huotari PR, Nupponen H, Laakso L, Kujala UM. Secular trends in aerobic fitness performance in 13-18-year-old adolescents from 1976 to 2001. Br J Sports Med. 2010;44:968-72.

22. Sallis JF, Owen N, Fisher EB. Ecological models of health behavior. In: Glanz K, Rimer BM, Viswanath K, editors. Health behavior and health education: theory, research, and practice. 4th ed. San Francisco: Jossey- Bass; 2008. p.487-505.

23. Tomkinson GR. Secular trends in fitness performance of Australasian children and adolescents. Adelaide: University of South Australia; 2004.

24. Tuckman B, Harper B. Conducting Educational Research. $6^{\text {th }}$ ed Lanham: Rowman Littlefield Publishers; 2012.

25. Boileau RA, Lohman TG, Slaughter MH. Exercise and body composition of children and youth. Scand J Sports Sci. 1985;7:17-27.

26. Ross WD, Marfell-Jones MJ. Kinanthropometry. In: Physiological testing of the high-performance athlete. MacDougall D, Wenger $\mathrm{H}$, Green $\mathrm{H}$, editors. Champaign: Human Kinetics Books; 1991. p. 223-308.

27. American Alliance for Health, Physical Education, Recreation and Dance. Health related physical fitness: Test manual. Reston: AAHPERD; 1980.

28. Cooper Institute for Aerobics Research. FITNESSGRAM Test Administration Manual. Dallas: CIAR; 1987

29. Maroco J. Análise estatística com utilização do SPSS. Lisboa: Edições Sílabo; 2007.

30. Adelino J, Vieira J, Coelho O. Sports participation in Portuguese young athletes. Lisboa: Instituto Desporto de Portugal; 2005.

31. Cardoso HF, Padez C. Changes in height, weight, BMI and in the prevalence of obesity among 9- to 11-year-old affluent Portuguese schoolboys, between 1960 and 2000. Ann Hum Biol. 2008;35:624-38.

32. Matton L, Duvigneaud N, Wijndaele K, Philippaerts R, Duquet W, Beunen G, et al. Secular trends in anthropometric characteristics, physical fitness, physical activity, and biological maturation in Flemish adolescents between 1969 and 2005. Am J Hum Biol. 2007;19:345-57.

33. Dos Santos FK, Prista A, Gomes TN, Daca T, Madeira A, Katzmarzyk $\mathrm{PT}$, et al. Secular trends in physical fitness of Mozambican school-aged children and adolescents. Am J Hum Biol. 2015;27:201-6.

34. Jurimae T, Volbekiene V, Jurimae J, Tomkinson GR. Changes in Eurofit test performance of Estonian and Lithuanian children and adolescents (1992-2002). Med Sport Sci. 2007;50:129-42.

35. Albon HM, Hamlin MJ, Ross JJ. Secular trends and distributional changes in health and fitness performance variables of 10-14-year-old children in New Zealand between 1991 and 2003. Br J Sports Med. 2010;44:263-9

36. Moliner-Urdiales D, Ruiz JR, Ortega FB, Jimenez-Pavon D, Vicente- 
Rodriguez G, Rey-Lopez JP, et al. Secular trends in health-related physical fitness in Spanish adolescents: the AVENA and HELENA studies. J Sci Med Sport. 2010;13:584-8.

37. Malina RM. Secular trends in growth, maturation and physical performance: A review. Przeglad Antropologiczny - Anthropol Rev.
2004:67:3-31

38. Nevill A, Tsiotra G, Tsimeas P, Koutedakis Y. Allometric associations between body size, shape, and physical performance of Greek children. Pediatr Exerc Sci. 2009;21:220-32. 